\title{
Studi Naskah: Menjadikan Lembaran Teks Sebagai Objek
}

\author{
Ismail Suardi Wekke \\ Sekolah Tinggi Agama Islam Negeri (STAIN) Sorong \\ Email: iswekke@stainsorong.ac.id
}

Assalamu Alaikum Warahmatullahi Wabarakatuh

Saudara (i) Sekalian.

Diskusi kita kali ini dalam mata kuliah Studi Naskah terkait dengan naskah sebagai lapangan kajian atau penelitian. Pertemuan kita sebelumnya membahas terkait dengan alat analisis yang digunakan ketika bertemu dengan sebuah naskah.

Capaian pembelajaran kita sesi ini: "mahasiswa mampu menganalisis naskah dengan menggunakan pendekatan multidisiplin dan/atau interdisipliner".

Studi naskah yang dimaksud bukan naskah yang dikenal dengan filologi tetapi naskah dalam arti pustaka. Untuk itu, jika ada kata naskah yang saya gunakan, maka sepenuhnya merujuk kepada pustaka.

Publikasi yang baru saja terbit dapat menjadi contoh:

https://www.researchgate.net/publication/338439446_Oral_and_Written_Traditions_of_Bugines e_Interpretation_Writing_Using_the_Buginese_Language_in_South_Sulawesi.

Artikel tersebut tafsir berbahasa Bugis yang diterbitkan Majelis Ulama Indonesia Sulawesi Selatan. Teks dalam hal ini tafsir dijadikan sebagai bahan kajian sekaligus dilihat tidak hanya dalam aspek sebagai teks semata tetapi dikaitkan dengan topik budaya Bugis.

Di tingkat magister, bacaan tidak hanya terkait dengan satu aspek saja, akan tetapi akan sangat bagus kalau menelusuri pelbagai aspek dengan pendekatan multidisiplin.

Berikut ini artikel terkait bahasa Arab (Wekke, 2014):

https://www.academia.edu/25601132/KITAB_SUCI_BAHASA_ARAB_DAN_PEMBACAAN_ TEKS_TINJAUAN_FILSAFAT_MOHAMMED_ARKOUN

Dalam menulis artikel tersebut, sepenuhnya Arkoun menjadi objek kajian dengan focus menganalisis apa yang menjadi pikiran dan karya Arkoun yang tertuang dalam teks.

Masih dengan aspek yang sama, bahasa Arab (Wekke, 2013):

https://www.academia.edu/8095014/TINJAUAN_MOHAMMAD_ARKOUN_TENTANG_BA HASA_ARAB_TEKS_DAN_SEMIOTIKA_AL-QUR_AN

Artikel ini juga mengelaborasi bahasa Arab dengan analisis yang berbeda. 
Sementara sebuah teks dapat didekati dengan tema tertentu. Seperti korupsi (Wekke \& Yusuf, 2018):

https://www.researchgate.net/publication/327587881_The_Corruption_in_Religious_Text_and Local_Wisdom_Perspectives_in_Bugis_Society.

Begitu pula dengan tema adopsi anak (Yusuf \& Wekke, 2018):

https://www.researchgate.net/publication/330647988_Child_Adoption_Practices_in_the_Bugis Community_Between_Bugis_Tradition_and_Ulama_Views.

Terakhir, saya mengemukakan sebuah buku (Wekke, 2019) dengan judul Islamisasi Bugis. Buku tersebut merupakan disertasi yang dikonversi menjadi buku, penelitian terkait Islam dan Bugis dengan obyek pada naskah Lontara.

Demikian, saudara (i), Bapak/Ibu. Selamat belajar... ingat luaran matakuliah kita berupa dua hal 1) review buku yang merupakan penelitian teks, dan 2) artikel praktik menganalisis naskah/teks.

Terima kasih

Wassalamu alaikum warahmatullahi wabarakatuh.

\section{Daftar Pustaka}

Wekke, I. S. (2013). Tinjauan Mohammad Arkoun tentang Bahasa Arab, Teks dan Semiotika AlQur'an. Al-Fikr, 17 (1), 64-80.

Wekke, I. S. (2014). Kitab Suci, Bahasa Arab dan Pembacaan Teks: Tinjauan Filsafat Mohammed Arkoun. Ulumuna, 18(2), 243-268.

Wekke, I. S. (2019). Perjumpaan Agama dan Tradisi Masyarakat Sulawesi Selatan: Bacaan Terhadap Buku Islamisasi Bugis. https://doi.org/10.31227/osf.io/8qihg.

Wekke, I. S., \& Yusuf, M. (2018). The Corruption in Religious Text and Local Wisdom Perspectives in Bugis Society. IBDA: Jurnal Kajian Islam dan Budaya, 16(1).

Yusuf, M., \& Wekke, I. S. (2018). Child Adoption Practices in the Bugis Community: Between Bugis Tradition and Ulama Views. Al-'Adalah, 15(1), 73-100.

Yusuf, M., \& Wekke, I. S. (2019). Oral and Written Traditions of Buginese: Interpretation Writing Using The Buginese Language in South Sulawesi. International Journal of Psychosocial Rehabilitation, 23 (4): 884-894. 